\title{
PROVIDING AN ENTREPRENEURIAL RESEARCH FRAMEWORK IN AN ENTREPRENEURIAL UNIVERSITY
}

\author{
NADERIBENI Nahid ${ }^{1}$, SALAMZADEH Aidin ${ }^{2}$, \\ RADOVIC MARKOVIC Mirjana ${ }^{3}$
}

\author{
${ }^{I}$ College of Farabi, University of Tehran, Qom (IRAN) \\ ${ }^{2}$ Faculty of Management, University of Tehran, Tehran (IRAN) \\ ${ }^{3}$ Institute of Economic Sciences, Belgrade (SERBIA) \\ Emails:n.naderi.b@ut.ac.ir, salamzadeh@ut.ac.ir,mradovic@gmail.com
}

\begin{abstract}
While researches and commercialization of the results have been considered to a greater extent at entrepreneurial universities, the distinction between academic and entrepreneurial researches has not been addressed. Therefore, the purpose of this study is to understand the concept of entrepreneurial research which presents a more comprehensive and complete view of the entrepreneurial university and then to provide a framework that helps to comprehend this concept in universities. This study has been conducted using a constructionist grounded theory. The methodology of a structuralist grounded theory is an attempt to collect multiple but heavily focused data to identify and develop concepts. In this study, theoretical sampling and semi-structured interviews were used to collect data. In this framework, the extracted main categories including governance in universities, communication with industry, entrepreneurial training, entrepreneurial research functions, cultural and social requirements, entrepreneurial research and commercialization are the results of the research. Entrepreneurial research functions are summarized in value creation, innovation and technique creation. The value of this research is firstly to identify the gap between academic and entrepreneurial researches, and secondly to formulate and provide a framework for the concept of entrepreneurial research in universities. The results of this research provide a framework for higher education policymakers and planners to develop an entrepreneurial approach in academic researches. Applying this framework will also reduce the unemployment rate of alumni in the society, and the employment of alumni will increase the economic growth of the societies.
\end{abstract}

Keywords: Entrepreneurial university, entrepreneurial research, value creation, communication with industry, commercialization

JEL: $L 26$

UDC: 005.344:005.573.001.891:005.342

COBISS.SR-ID: 18170889

\section{Introduction}

New universities have a catalyst role for entrepreneurship by replacing the old with new educational and research systems for operating and modelling new businesses. For this reason, universities around the world have significantly expanded their curricula for entrepreneurship [1], [2], [3]. However, the number of students who have started entrepreneurial activities has not yet increased at a reasonable rate [4]. In Iran, entrepreneurship was implemented in 12 universities with more than a 20year delay compared with developed countries. In the late 2000s, based on the fourth economic, social and cultural 
development plan of the Islamic Republic of Iran, a project entitled "KARAD", was introduced to help solve the unemployment problem among alumni. "Enhancing and fostering entrepreneurial knowledge through entrepreneurship research and training in universities and higher education centres" have been emphasized in the aims section of this regulation.

Nevertheless, 18 years after this plan, the universities of Iran were not integrated with new (entrepreneurial) approaches. Emerging economies have shown the highest rate of research growth in 2018 based on estimations of the Clarivate analytics publishing institute, and also Iranian Scientific Publications have increased by more than $8 \%$ in comparison with the year 2017. However, 50,000 researches are annually conducted without an applicant (Hamshahri newspaper 2018), and much time is spent on these researches. Meantime, the share of university alumni out of the number of total unemployed individuals in Iran is $40.5 \%$ (Statistical Center of Iran 2019). Therefore, it is expected that some results of theses from faculties or researches will help to create business and student entrepreneurship and solve the unemployment problem, but this is not the case. Also, there are no facts or even estimations about how many student theses and faculty researches have been commercialized in Iran. One of the significant problems in Iran and other developing countries is that academic researches, especially dissertations, do not usually have a clear and defensible justification for various sections, especially in industry. As a result, they have not entrepreneurship capability.

Universities also tolerate high costs for academic researches to be carried out, which is not in line with the modern university approach. While creating entrepreneurship using research results will reduce the financial erosion of universities, it must be noted that some of these alumni have entered the universities as faculty members and, because they have been trained in the traditional way, this defective cycle continues and their students are trained and graduate with the same traditional view. Therefore, the critical issue is what re-definition universities should provide from their researches to evoke the concept of entrepreneurial research? Moreover, what framework, over time, can increase the capacity of universities to do entrepreneurial researches for correction of the above-mentioned defective cycle?

Therefore, this study first attempts to clarify the concept of entrepreneurial researches then to provide a framework for carrying out entrepreneurial researches in universities using the grounded theory approach. At first, the value of this research is to identify the gap between scientific and entrepreneurial researches and second, about the aim to develop and provide a framework for doing entrepreneurial researches in universities.

\section{Theoretical Background}

Universities are always involved in teaching and research Ben-David and Zloczower [5].

In the beginning, universities generally taught and prepared students in the fields of law, medicine, and theology, professionally. Then, Humboldt provided a model after which universities began to research [6]. In the second half of the $20^{\text {th }}$ century, the development of new industries was based on university researches [7]. Over the recent 50 years, all industrialized countries and also the developing countries have paid attention to development of economic growth, technology and innovation by making people aware of the importance and decisive role of research [8], [9], [10] focused their attention on enhancing the level of different research indexes. Kirsty Newman et al., team leader of the evidence into action team in DFID stated that investing in research helps the development of societies in four ways: in economic growth, social capital upgrading, technological development and notification for policies and practices [11]. Therefore, the countries with the most investment in research have more social capital, technology and advanced industries. Universities are the most important places for the production of science due to having the highest intellectual and spiritual capacities; therefore, organizing academic researches is one of the most important effective 
factors on the overall progress and sustainable development of societies. But how should this be organized? And what is the difference in the nature and outcome of research in universities? Research at university can be divided into two academic and entrepreneurial types of research by comparing the two Merton and Gibbons models in producing science.

The re-reading of the position of science shows that the Merton model formed mainstream scientific production before the publication of Michael Gibbons et al.'s book named "New method of producing science" in 1994. However, after the publication of the book, the trend changed, and it was considered a critical moment in dialogue about how universities and institutes of higher education and research should be managed in Europe [12]. Gibbons called the new method of producing science as the second model of science, which is opposed to the traditional method of producing science or the first model of knowledge [13]. The Merton model is an ancient paradigm in scientific discoveries and has been founded on the domination of theoretical or empirical sciences, the endogen of fields and independence of scientists from host organizations or universities and has no relationship with political and economic equations and necessities [14].While, the second model is based on three trends: prioritization management, commercialization, and responsiveness of the produced knowledge [15]. Therefore, the second model emphasizes the commercialization of higher education and regarding science and knowledge as goods from the industry and the private section. In the Merton model, individuals have the role of a scientist (fundamental and pure scientist). However, in the second model, the individuals have the role of a researcher (practical scientist, technologist and industrial researcher). Table 1 summarizes the differences between the two views. The characteristics of academic and entrepreneurial research are determined considering this pluralization and can distinguish them from each other:

Table 1. Traits of academic and entrepreneurial research

\begin{tabular}{|c|c|c|}
\hline Academic research & Traits & Entrepreneurial research \\
\hline $\begin{array}{c}\text { The industrial age and } \\
\text { before it }\end{array}$ & History (Jacob [12]) & The post-industrial age \\
\hline $\begin{array}{c}\text { From the first pattern - } \\
\text { Merton }\end{array}$ & The origin (Nowotny [13]) & From the second pattern - Gibbons \\
\hline Long-term & $\begin{array}{l}\text { Duration of emergence } \\
\quad \text { (Nowotny, [13]) }\end{array}$ & short-term \\
\hline Fundamental & $\begin{array}{l}\text { Type of research (Delanty, } \\
{[14] \text { ) }}\end{array}$ & Practical \\
\hline With communication & $\begin{array}{c}\text { Communication with } \\
\text { political and economic } \\
\text { equations and necessities } \\
\text { [14] }\end{array}$ & without communication \\
\hline $\begin{array}{l}\text { Scientists' independence } \\
\text { from host organizations or } \\
\text { universities (strong } \\
\text { academic freedom) }\end{array}$ & $\begin{array}{l}\text { The level of freedom } \\
\text { (Oliveira, [52]) }\end{array}$ & $\begin{array}{l}\text { Researcher's dependence on scientific activities } \\
\text { with economic and political institutions }\end{array}$ \\
\hline $\begin{array}{l}\text { Scientist (fundamental and } \\
\text { pure scientist) }\end{array}$ & $\begin{array}{l}\text { The role of people } \\
\text { (Gibbons, 2001 \& 2003) }\end{array}$ & $\begin{array}{l}\text { Researcher (practical scientist, technologist and } \\
\text { industrial researcher) }\end{array}$ \\
\hline $\begin{array}{l}\text { University is a growing } \\
\text { place for science production }\end{array}$ & $\begin{array}{l}\text { Beneficiaries (Oliveira, } \\
{[\text { [52]) }}\end{array}$ & $\begin{array}{c}\text { The university is no longer the privileged place } \\
\text { of producing science. Knowledge is produced } \\
\text { with other actors and institutions using new } \\
\text { compositions and formulations from scientific } \\
\text { knowledge }\end{array}$ \\
\hline Specialists of the field & $\begin{array}{l}\text { Determinants of scientific } \\
\text { needs } \\
\text { (Nowotny, [13] [15]) }\end{array}$ & $\begin{array}{c}\text { Applicants like planners and policy makers on } \\
\text { the one hand and users and beneficiaries as } \\
\text { consumers on the other }\end{array}$ \\
\hline $\begin{array}{l}\text { Based on endogenous of the } \\
\text { feils and in the scientific }\end{array}$ & $\begin{array}{l}\text { The power and location of } \\
\text { science production }\end{array}$ & $\begin{array}{l}\text { Based on the endogenous (determining the effect } \\
\text { of scientific supernatural factors) social factors }\end{array}$ \\
\hline
\end{tabular}




\begin{tabular}{|c|c|c|}
\hline Academic research & Traits & Entrepreneurial research \\
\hline communities & (Delanty, [14]) & $\begin{array}{l}\text { (on scientific facts and in the market and industry } \\
\text { communities) }\end{array}$ \\
\hline Manufacturer of science & $\begin{array}{l}\text { The role of the university } \\
\text { (Nowotny, [13], Delanty, } \\
\text { [14]) }\end{array}$ & $\begin{array}{l}\text { Intermediation between the production of science } \\
\text { (market-industry) and the consumer of science }\end{array}$ \\
\hline University science course & $\begin{array}{c}\text { Academic } \\
\text { course(Nowotny, [13], } \\
\text { Delanty, [14]) }\end{array}$ & Post-academic science \\
\hline $\begin{array}{l}\text { In the traditional } \\
\text { universities }\end{array}$ & $\begin{array}{c}\text { Type of the university } \\
\text { (Nowotny, [13], Delanty, } \\
[14])\end{array}$ & At modern-entrepreneur universities \\
\hline Specialized fields & $\begin{array}{l}\text { Field structure } \\
\text { (Gibbons,2003:3) }\end{array}$ & Transdisciplinary \\
\hline $\begin{array}{l}\text { Understanding and } \\
\text { explaining phenomena in } \\
\text { the research }\end{array}$ & $\begin{array}{l}\text { Researcher's concern } \\
\text { (Gibbons, 2003:3) }\end{array}$ & Improving social status, productivity \\
\hline $\begin{array}{l}\text { Extending the domain and } \\
\text { area of science from the } \\
\text { scientific communities }\end{array}$ & $\begin{array}{l}\text { Consequences (Nowotny, } \\
\text { Scott \& Gibbons, [15]) }\end{array}$ & $\begin{array}{l}\text { Commercialization of research results and } \\
\text { creation of new companies and factories with } \\
\text { cooperation of academics and non-academics } \\
\text { (industry and private sector) }\end{array}$ \\
\hline $\begin{array}{l}\text { Understanding truth and } \\
\text { enlightenment }\end{array}$ & $\begin{array}{l}\text { Consideration from the } \\
\text { science } \\
\text { ([15], (Gibbons, 2003:3) }\end{array}$ & Goods-productivity \\
\hline Academic & $\begin{array}{l}\text { Researches management } \\
\text { (Nowotny, [13] }\end{array}$ & Corporate and capitalism \\
\hline Open minded & Faculty (Delanty, [14]) & Contractor researcher \\
\hline Individual & $\begin{array}{l}\text { Responsibility for the } \\
\text { results (Nowotny, [13]) }\end{array}$ & Social responsibility, accountability, flexibility \\
\hline More identical & $\begin{array}{l}\text { Research skills } \\
\text { (Nowotny, [13]) }\end{array}$ & Heterogeneous and numerous \\
\hline Government & $\begin{array}{l}\text { Location of providing the } \\
\text { research credits } \\
(\mathrm{Jacob},[12])\end{array}$ & Private sector \\
\hline
\end{tabular}

Another way of identifying the concept of entrepreneurial research is to pay attention to the definitions provided by the Entrepreneurial University. Having an overall understanding and providing a clear picture of Entrepreneurial Universities is not just about training but also academic researches and is one of the crucial elements of an Entrepreneurial University and entrepreneurial research. Furthermore, previous studies have shown a positive correlation between researches and entrepreneurial activities [16].

As mentioned in the previous section, in the second model of science production, a powerful market-industry entity was included in the university interactions, which is considered as one of the essential characteristics of a modern university today. Nelson [17] has considered the modern university as an Entrepreneurial University. Also, Dabic et al., [18] have argued that in a typical entrepreneurial university, all members' activities are managed and implemented in a way that the university becomes an economic entity or subcompany. It means the orientation of these activities should be profitable and gain competitive advantages [18]. Table 2 has provided the definitions for entrepreneurial researches according to the definitions provided by the Entrepreneurial University. 
Table 2. Entrepreneurial university and entrepreneurial research

\begin{tabular}{|c|c|}
\hline Entrepreneur University & Entrepreneurial research \\
\hline $\begin{array}{l}\text { Commercialization of knowledge (Etzkowitz [54], [55]; Guenther \& } \\
\text { Wagner, [56]) }\end{array}$ & $\begin{array}{l}\text { Its results should be } \\
\text { commercialized }\end{array}$ \\
\hline $\begin{array}{c}\text { Communication with industry (Etzkowitz, } 1984 \& 2003 \text { [57], [40]); } \\
\text { (Kirby et al., [31]) }\end{array}$ & $\begin{array}{l}\text { The needs of the industry should } \\
\text { be solved }\end{array}$ \\
\hline Search for funds (Etzkowitz, [54]; Kirby et al., [31]) & $\begin{array}{l}\text { The private sector supplies its } \\
\text { funds }\end{array}$ \\
\hline $\begin{array}{l}\text { Producing and utilizing the Knowledge (Etzkowitz [54], [55]; Guerrero et } \\
\qquad a l .,[57],[58])\end{array}$ & $\begin{array}{l}\text { The applicability of the research } \\
\text { results }\end{array}$ \\
\hline $\begin{array}{l}\text { Participating in regional social and economic development (Etzkowitz, [40]); } \\
\text { (Kirby et al., [31]) } \\
\text { (Guerrero et al., [59]); Salamzaeh } \text { et al., [60], [61]) }\end{array}$ & $\begin{array}{l}\text { Its results lead to the social and } \\
\text { economic development of } \\
\text { society. }\end{array}$ \\
\hline $\begin{array}{l}\text { The university is regarded as an institution or quasi-corporation } \\
\text { (Gibbons, [56]); Dabic et al., [56]) }\end{array}$ & $\begin{array}{l}\text { Establishing as a result of } \\
\text { commercializing that company. }\end{array}$ \\
\hline $\begin{array}{c}\text { Identify creative attitude an opinion that can be converted into new } \\
\text { investments (Fayolle \& Redford, [62]) }\end{array}$ & $\begin{array}{l}\text { Its results can be converted into } \\
\text { new investments }\end{array}$ \\
\hline A driving force for emerging industrial and social innovation (Romero, [29]) & $\begin{array}{l}\text { It acts as a motive force for } \\
\text { industrial and social innovation }\end{array}$ \\
\hline $\begin{array}{l}\text { It has developed, based on the triple helix idea, and confirms innovation as } \\
\text { one of the stimulus vectors of the relationship between the university, } \\
\text { government and industry (Etzkowitz, [54], [63]) }\end{array}$ & Should be innovative. \\
\hline $\begin{array}{l}\text { Faculty member are looking for opportunities to commercialize innovation } \\
\text { (Mustar Renault et al., [64]) }\end{array}$ & $\begin{array}{l}\text { By identifying opportunity - } \\
\text { innovation }\end{array}$ \\
\hline $\begin{array}{l}\text { Universities which consider new funds such as patents, contract research and } \\
\text { partnerships with a private company (Etzkowitz [57]) }\end{array}$ & Lead to patents and patents \\
\hline $\begin{array}{c}\text { A commercial university is involved with creating new commercial } \\
\text { partnerships by university professors, technicians, or students, } \\
\text { Chrisman } \text { et al., [53] }\end{array}$ & Lead to business partnerships. \\
\hline $\begin{array}{l}\text { Transferring technology of the university is as formal efforts to invest in the } \\
\text { academic researches (Dill \& Sporn [65]) }\end{array}$ & $\begin{array}{l}\text { Its results will lead to the } \\
\text { development of technology } \\
\text { transfer. }\end{array}$ \\
\hline $\begin{array}{l}\text { An Entrepreneur University seeks alone innovation in business manner } \\
\text { (Clark, [66]) }\end{array}$ & $\begin{array}{l}\text { Its results will lead to innovation } \\
\text { in business manner }\end{array}$ \\
\hline $\begin{array}{l}\text { Entrepreneurial universities, like the heart of any entrepreneurial culture, } \\
\text { have the ability to innovate, identify and create opportunities, work in teams, } \\
\text { take risks and respond to challenges (Kirby, [67]) }\end{array}$ & $\begin{array}{l}\text { Its results will be responsive to } \\
\text { the challenges in society. }\end{array}$ \\
\hline
\end{tabular}

To follow, after identifying the characteristics of entrepreneurial researches that are provided in Tables 1 and 2, a framework has been provided for entrepreneurial researches in universities through grounded theory.

\section{Research Methodology}

This research, with a qualitative approach, seeks to respond to the framework method of entrepreneurial researches through discovery. The qualitative approach includes different perspectives and schools, one being a context-based theory [19]. In a segmentation, classical and new styles of grounded theory have been divided into two objectives and constructionist categories. This research is placed in the group of constructionist grounded theory. The methodology of constructionist grounded theory attempts to collect multiple but heavily focused data to identify and develop the concepts. There is also a pragmatic basis for it. In the epistemological dimension, Charms believes that constructionist grounded theory is the discovering of a version of reality as a result of the interaction of the researcher and the data [20]. Constructionist grounded theory has emerged as a result of the development of constructionist theories in the social sciences. This approach seeks to understand social phenomena [21]. Therefore, the use of this method helps to reinforce an understanding of the 
social phenomenon of the Entrepreneurial University. Douglas [22] also believes: the method of grounded theory has a suitable methodology for research in entrepreneurial areas.

According to Charms' view [20], [21], theoretical sampling was used in this study to investigate exploratory answers for questions of the research and the theoretical generalization of them. Semi-structured interviews were used to collect data. The interviewees were divided into three groups: a) members of the faculty of Iran's public universities (36 people); B) entrepreneur alumni of the universities who had established a company or startup after the thesis (12 people); C) Employers / entrepreneurial managers of the private companies (3 people). Each interview lasted around 30 to 45 minutes. All interviews were written according to Charms' theories (2006) and are used in three stages of open coding (to identify codes and concepts), centralized (for emerging core categories) and theoretical (to identify and integrate pivotal categories). Table 1 shows an example of codings.

\section{Research Findings}

Twenty-four centralized codes (concept) and six axial codes (theoretical) codes were extracted as a result of the three-stage coding of the collected data. Table 3 shows an example of coding.

Table 3. Example of concepts and codes extracted from data coding

\begin{tabular}{|c|c|c|}
\hline Open coding (references or primary codes) & $\begin{array}{c}\text { Centralized } \\
\text { coding } \\
\text { (concepts) }\end{array}$ & $\begin{array}{c}\text { Axial coding } \\
\text { (axial categories) }\end{array}$ \\
\hline $\begin{array}{l}\text { The purpose of research in traditional universities is knowledge } \\
\text { production and the purpose of research in the Entrepreneur University is } \\
\text { value creation. Value creation means providing a new idea from a } \\
\text { research. Demand-oriented research. The economic value of an educated } \\
\text { human cannot be calculated. Being latent of the value of public and } \\
\text { social benefits in the word value. Transferring from training approach to } \\
\text { research and from research to entrepreneurship for value creation. } \\
\text { Converting the oil economy into an economy based on demand-oriented } \\
\text { new knowledge and technologies, reproducing various cultural, human- } \\
\text { social investments. }\end{array}$ & $\begin{array}{l}\text { 1. value } \\
\text { creation }\end{array}$ & $\begin{array}{l}\text { 1. Functions of } \\
\text { entrepreneurial } \\
\text { research }\end{array}$ \\
\hline $\begin{array}{l}\text { Creating innovation in entrepreneurship, involving the human mind with } \\
\text { innovations and new methods. Most innovations come from conscious } \\
\text { and purposeful searches and through the analysis of new opportunities. } \\
\text { The rise of the innovative researcher and their use of all senses and } \\
\text { perceptions in providing new work, studying the new designs. Formation } \\
\text { of entrepreneurship based on new innovation and technology. Consider } \\
\text { reducing costs and increasing the quality of products or services in } \\
\text { innovations. }\end{array}$ & 2. Innovation & \\
\hline $\begin{array}{l}\text { Attention to the resultant of entrepreneurship and technology interaction. } \\
\text { The use of up-to-date science and technology by the researcher, the } \\
\text { benefit of the people in the society from more prosperity through new } \\
\text { technology. Drawing the horizons and opportunities for new technology } \\
\text { creation by the university, the need to build the infrastructure for the } \\
\text { emergence of new technologies in the society ... }\end{array}$ & $\begin{array}{l}\text { 3. Technique } \\
\text { creation }\end{array}$ & \\
\hline
\end{tabular}

\section{Category sample: entrepreneurial research (category number 1)}

The first category of data is the functions of entrepreneurial research. This category consists of three concepts: value creation, innovation and technique creation.

\section{A. Value creation:}

If research is conducted and did not create value, it cannot help the development of the society. In this regard, one faculty member believed that "the share of any research value can 
be calculated through the level of problems in society. A young person who, after finishing their education and through the results of their research, puts what they have created into practice and creates value for society and for himself, this student is not a girl or boy who wastes their youthful energy and has no benefit for themselves nor their society"

Another interviewee summarized value in three ways:

"In my opinion, value in research means those researches which are based on demand. I mean real demands, not false ones. If any company hands over a topic or any subject to a university just because of assigning one percent of its budget to research and development, I call them false demands which will not solve any problems. Producing capital is another value in research. Values such as human, social, cultural and intellectual capital are created only in research teams. And the third value is to consider public interests. Especially, when we talk about sustainable value, public interests are redefined in the concepts such as the environment and human society".

\section{B. Innovation:}

It is not possible to create value from research without innovation. If creative ideas for a new business are successfully implemented, innovation will be converted to entrepreneurship. In this regard, the CEO of a confectionery factory, who is also the founder of a university of practical science said: "At first, I didn't think I could globalize my products, but we were able to reach such a position with a bit of reflection and attention to new tastes of people. I first asked my university researchers (students and professors) to research more about tastes. When research progressed, we discovered new factors such as changing the shape of Gaz, the mixture of Gaz with other sweets and even the type of packaging. For example, we designed the shape of the sweet tins like the cover of Hafiz's book of poetry, or mixed it with the famous Sohan of Qom, which was greatly welcomed $t$ such an extent that this product has been exported to Canada, North America, European countries, China and other countries."

The CEO of a software company said: "I always advise students, professors, and researchers to choose an endogen idea to start with which should be evaluated in two ways, one way is related to the concerns which arise in research, and the other is consistent with the needs of the society. Fortunately, we have had good results in the software production area, and we have had a $20 \%$ increase in the sales department compared to last year. This progress was due to two students' effort that helped us to reach our goal in the sales and marketing departments, by providing a new idea in their thesis".

\section{Technique creation:}

In recent years, the relationship between knowledge and technology has been integrated so much that it is difficult to separate the realm of each of them practically, and may even be impossible in some cases. A person who creates a technique starts to create employment by utilization of the science and knowledge of the day. The CEO of a technology company expressed: "in the new technologies area, knowledge has special importance. New technologies have a very high growth rate, and much value is added. This is because of the direct use of people's knowledge. For example, the cost of raw materials in an IC is negligible, but it becomes very valuable with suitable processing. In traditional business, the highest cost is spent on raw materials. You make money or better to say you convert electrons into money in the business of information technology area without raw materials and solely with technical knowledge. So, in businesses which are related to new technologies, creative human resources and the costs people have spent on gaining knowledge are the main sources".

The CEO of a knowledge-based company in the area of nano said: "Firstly, I tell the students not to get stuck in a creative block i.e nano in this case. Business is like a boxing match. When the opponent's guard is down, you must strike while the going's good. The students must be ready. The old native Australians had something called boomerangs that 
they threw up into the air; it would hit the bird and come back. They did not target the bird's current location, but by predicting where the bird would be in the next 30 seconds, so they threw it ahead. Business is also like this. The students need to be aware, for example, Graphene is very much in high demand at the moment; they must look ahead and know how long it will take for a product to become a trending product? Those who thought about Graphene seven or eight years ago and worked hard to promote it are now the pioneers".

Fig. 1. Entrepreneurial research framework

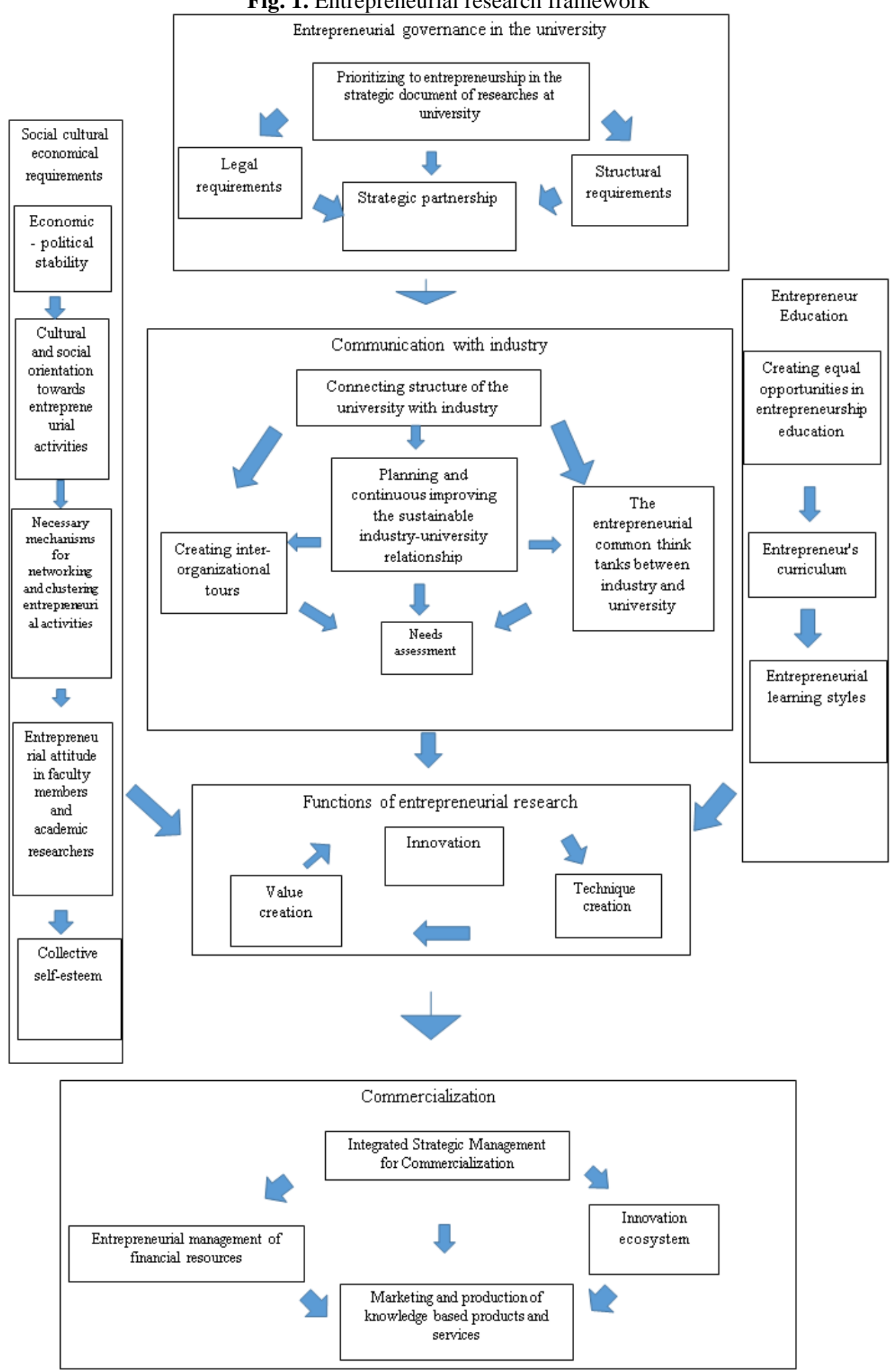

${ }^{\circ}$ Filodiritto Editore 


\section{Discussion}

In this study, we first tried to identify the concept of entrepreneurial research based on what is in theoretical basics. Then, a framework was provided for conducting entrepreneurial researches in the universities using Grounded theory. After analyzing the data from the interviews, the categories were extracted from the concepts.

The results of the analysis showed that entrepreneurial research has three important functions: innovation, value creation and technique creation which is consistent with viewpoints of Hitt et al., [23], Samson and Gloet [24], Koller et al., [25] in value creation; Crossan \& Apaydin [26], Lewrick et al., [27] and Drucker [28] in innovation and Atzkowitz (2001 and 2004), Romero [29] and Clark [30] in technique creation.

Relation with industry is another relevant category which is consistent with research results of (Atzkowitz 1984, 2003; Kirby et al., [31], Link et al., [32] and Etzkowitz \& Klofsten [33].

One of the best methods to communicate with industry is the interconnection of industry and university structures where the researcher believes they create the "twin structures", an organization which has been created on a shared mission. There are structural dependency and synapse between them at the same time, each of them doing their duty. For example, providing think tanks and organizational tour offices in centres and organizations can be the connection synapses of two organizations. Experts and specialists should be present in the think tanks. However, through inter-agency tours, everyone from high-levels to operational, from professor to the student from industry to university or vice versa can gain experience and prepare themselves for innovation and entrepreneurship. In this view, it is assumed that the knowledge flow created with close audiences [in inter-agency tours], is different from the knowledge flow produced by the farther actors in the think tanks [34] where bonding happens first and bridging second.

We can create an effective role in reinforcing the think tanks and in inter-agency tours by planning and through continuous improvement in the relationship of industry-university.

Besides, the sustainable relationship between industry and university facilitates need assessment category and causes it to form due to the need of market, society, industry and university research issues. According to Paul Jones, the deputy director of the International Centre for Transformational Entrepreneurship at Coventry University in the United Kingdom, universities should try to concentrate more on entrepreneurship activities according to the needs of the society [35].

Before this connection, university governance needs to orient towards entrepreneurship. In order to form this governance, prioritization of entrepreneurship in university research, a strategic document is essential. This prioritization leads to the formation of structural and legal requirements. According to the interviewees, the structure of the organization facilitates the entrepreneurial researches, if it avoids certainty and is compatible, flexible, dynamic and organic, the roles in entrepreneurial teams are quickly undertaken based on accountability and the flow of free information. Furthermore, based on the interviewees' opinions, legal requirements are formed through the executive guarantee of having a protecting intellectual property law, shortening the time it takes for plan approval, eliminating or amending cumbersome rules, clarity of laws intellectual property, lack of unnecessary rigour in adopting research plans and issues, changing academic regulations in research section. According to Kerr \& Nanda [36] bureaucracy may neutralize innovations in the university.

After the formation of requirements, strategic partnerships are required for entrepreneurial research. Strategic cooperation goes along with strategic purposes of an academic college or university unit. It shows the multidimensional interaction between the involved devices and a diverse range of activities with the purpose of mutual benefit of the parties (Matthias Kuder quoted from Caspar-Terizakis and $\mathrm{Yu}$ [37]. 
One of the facilitators of entrepreneurial research is entrepreneurial education. From the perspective of Gibb [38] education helps entrepreneurship in universities more than other factors. This training can be explained by an entrepreneurial curriculum, entrepreneuriallearning styles and by creating equal opportunities in entrepreneurship training.

Characteristics of the entrepreneur curriculum include demand-driven, curriculum updates, using an interdisciplinary and transdisciplinary approach, emphasis on the purpose of higher levels of Bloom's classification, teaching the technique of wealth creation, student evaluation based on ideas, creativity and innovation, equipping training space and place for teaching entrepreneurship training which is consistent with a perspective of Shepherd and Douglas [39] (1997) Etzkowitz [40] (2003) and Robles [41] (1998).

The next facilitator is in the framework of entrepreneurial researches on cultural and social requirements. One of these requirements is political stability, followed by economic stability.

According to the participants, maintaining political and economic stability is considered as one of the important factors to support an entrepreneurial researcher, especially in developing countries, and this is a way to avoid the single-product economy (oil), more dependency on academic budgets on the income caused by commercialization of research results, reducing the exchange rate and equity fluctuations and its effect on the provision of research instruments, reducing managerial displacements, not forcing entrepreneurs in unproductive economic practices, having a positive balance of economic performance in the society, making stable but flexible decisions, sustainable activities of political institutions such as government and parliament for academic entrepreneurship, and developing neutral rules for entrepreneur researchers.

It seems that political factors, in particular, have a significant effect on socio-cultural orientation towards entrepreneurship. According to the interviewees, this orientation could be in the form of theoretical coherence in the entrepreneurship issue among policymakers, planners and executives, eliminating discrimination of gender, religious and regional, social media roles in supporting entrepreneurial researches, maintaining a suitable position for industry and small businesses, suitable mechanisms to respect and support entrepreneurial researchers, commitment to research ethics and intellectual ownership, developing a culture of hard work and risk-taking, social and cultural mobility in the area of entrepreneurship. It is essential to notice that the relationship between politics and culture is two-sided and paying attention to both will develop the economy of the society. Because, on the one hand, according to Muers [68], the legitimacy of public culture and entrepreneurial value systems is the result of adopting a desirable policy in the area of entrepreneurship, and on the other hand, there is empirical evidence that shows culture plays a role in determining specific political results and its overall approaches in different places [42] and better policies will be adopted in the area of entrepreneurial researches if the culture and entrepreneurial attitudes are strengthened. OECD [43] has reported that purpose, creating mentalities and entrepreneurial attitudes in people have been considered in some countries like Denmark and Britain for developing economically. Dewey \& Van Warren (2007), and Bosman and Fernhaber [44] also emphasized on this.

An entrepreneurial attitude creates and promotes collective self-esteem (one of the most important categories in cultural and social needs) among entrepreneurial researchers.

Collective self-esteem is very important in understanding the values and the entrepreneurial group beliefs, according to Luhtanen \& Crocker [45] and Frese [46].

According to the interviewees, collective self-esteem will be obvious in the form of the right to speak and respond among members of the research team, belief in the capabilities of research colleagues, helping research colleagues with the purpose of commercialization of results, reinforcing collective skills, reducing fear and sense of danger in research groups and creating a sense of belonging and loyalty to the research team. 
Networking entrepreneurial activities are also suitable facilitator for creating collective self-esteem. According to interviewees, finding professional groups and associations to help academic entrepreneurship, sharing information between university and industry, formulating a common strategy for networking between university and industry, integrating social capital through cultural networking, social networking for training entrepreneurial students are suitable mechanisms for networking. This part of the findings is consistent with Audretsch's opinions [51].

By considering these arrangements, commercialization of the research results would appear to be successful. Some authors, such as Lacetera [47] and Geuna, Salter \& Steinmueller [48] have considered academic entrepreneurship as direct involvement of academics in the commercialization of their research results. In general, many factors have led universities to change their attitudes about how to utilize research results. Environmental tensions and reduction of university financial resources, investors' willingness to research and develop, and government policies along with economic development, competition, utilitarianism, and neoliberalism are the related causes with the commercialization approach in the results [49].

Integrated strategic management is necessary for the commercialization that reduces complexity. It can be implemented and reinforced through different ways, such as designing a commercialization organization cycle, managing effectiveness of intellectual properties, utilizing the ERP system, utilizing the PDCA Deming cycle, integrating industrial, commercial and technology policies.

An innovation ecosystem is formed by integrated management, and according to the interviewees; resistance is formed against environmental shocks in entrepreneurship, organizing adaptive collaborations, the presence of entrepreneurial accelerators, coordination of planning institutions and guiding entrepreneurship and formation of innovation poles. If attracting dangerous capital exists for university entrepreneurs, setting up an entity or financing office of venture activities, setting up university insurance to support academic entrepreneurs, allocating part of the endowment for academic entrepreneurship, risky investment, providing financial grants to carry out entrepreneurial research, holding transparent tenders to do entrepreneurial research, the management of financial resources will itself be an entrepreneurial activity. It should be noted that financing limitation is one of the biggest concerns which affects potential entrepreneurs around the world [36] and they are facilitated by the mentioned arrangements.

According to interviewees, providing marketing services to researchers, utilizing the suitable strategies to create demand in the market, familiarity with advertising methods, experimental marketing, and familiarity with market secrets will facilitate marketing entrepreneurial researches, and all of them will speed up commercialization.

\section{Conclusion}

This research provides ideas for entrepreneurship. The role of two words, research and entrepreneurship together, will provide a more comprehensive and different perspective for the university's research mission. The university, as a science production base, must explain entrepreneurial knowledge about the economic and social issues of the society. Furthermore, entrepreneurial research must be supported through precise planning and policymaking.

Finally, entrepreneurs can utilize the results of universities research to their business. We can draw and suggest the framework of Table 2 for entrepreneurial researches in the universities by integrating the two categories of research and entrepreneurship and taking into consideration what has been studied. With this framework, it seems that the gap can be bridged between entrepreneurial research and entrepreneurship in universities. 
Practical results of the research: the results of this research provide a framework for higher education policy makers and planners to develop the entrepreneurial approach in academic researches.

Social results of the research: utilizing this framework reduces the unemployment rate of alumni in the society, and the employment of alumni will increase the economic growth of societies.

Research validation: two strategies have been used to validate this research: (i) review or feedback of counterparts [50], this considers the role of counterparts as the devil's advocate role. A person who is honest with the researcher asks challenging questions about methods, meanings, and interpretations, giving the researcher the opportunity to provide the attitude emotionally; (ii) Controlling the members that the researcher uses from the perspective of the participants to ensure the reliability of the findings and interpretations. This technique is considered as the most important technique for creating reliability [50].

\section{REFERENCES}

[1] (Dickson, P.H., Solomon, G.T. and Weaver, K.M. (2008). Entrepreneurial selection and success: do education matter? Journal of Small Business and Enterprise Development, 15(2): pp. 239-258.

[2] (Morris, M.H., Kuratko, D.F.and Cornwall, J.R. (2013). Entrepreneurship Programs and the Modern University, Edward Elgar, Cheltenham, UK.

[3] (Morris, N.M., Kuratko, D.F. and Pryor, C.G. (2014). Building blocks for the development of university-wide entrepreneurship, Entrepreneurship Research Journal, 4(1): pp. 45-68.

[4] Sieger, P., Fueglistaller, U. and Zellweger, T. (2014). Student Entrepreneurship across the Globe: A Look at Intentions and Activities, Swiss Research Institute of Small Business and Entrepreneurship at the University of St. Gallen (KMU-HSG), St. Gallen.

[5] Ben-David, J and Zloczower, A(1962).Universities and Academic Systems in Modern Societies, European Journal of Sociology, 3(1): pp. 45-84.

[6] Altbach, P.G(2011). The Past, Present, and Future of the Research University (Chapter 1): from book: The Road to Academic Excellence, Editors: Philip G. Altbach and Jamil Salmi, The International Bank for Reconstruction and Development/The World Bank: Washington DC.

[7] Solomon, G.T., Weaver, K.M., Fernald, L.W., 1994. A historical examination of small business management and entrepreneurship pedagogy. Simul. Gaming, 25 (3), pp. 338-352.

[8] Allen, T. (1977). Managing the Flow of Technology. MIT Press.

[9] Jaffe, A. B. (1989). Real Effects of Academic Research, American Economic Review 79(5): pp. 957970.

[10] Rosenberg, N., and Nelson, R. (1994). American Universities and technical advance in industry, Research Policy, 23: pp. 323-348.

[11] DFID (Department for international Development). (2014). What is the evidence on the impact of research on international development? https://assets.publishing.service.gov.uk/...pdf.

[12] Jacob, M. (2005). Boundary Work in Contemporary Science Policy: A Review, Prometheus, 23(2): pp. 195-207.

[13] Nowotny, H (2006). Real science is excellent science - how to interpret post-academic science, Mode 2 and the ERC, Journal of Science Communication, 5(4): pp. 1-3.

[14] Delanty, G (2001). University in Knowledge Society, SAEG, Organization, 8(2): pp. 149-153.

[15] Nowotny, H., Scott, P., Gibbons, M. (2001). Re-Thinking Science: Knowledge and the Public in an Age of UncertaintyPolity, PressCambridge.

[16] Stefan Houweling, V. (2017). Commercialization of Academic Research, Dissertation, Universität Siegen.

[17] Nelson, L. (2001) 'The entrepreneurial university', in A.H. Teich, et al., (Eds.) AAAS Science and Technology Policy Yearbook (2001), American Association for the Advancement of Science, Washington.

[18] Dabic, M Gonz_alez-Loureiro, M, Daim, T, U. (2015). Unraveling the attitudes on entrepreneurial universities: The case of Croatian and Spanish universities, Technology in Society, 42: pp. 167-178.

[19] Flik, U. (2006). An Introduction to Qualitative Research, London, Sage Publications.

[20] Charmaz, K. (2006). Constructing grounded theory: a practical guide through qualitative analysis. London: SAGE Publications. 
[21] Charmaz, K (2008). Constructionism and the Grounded Theory Method. In J.A. Holstein \& J. F. Gubrium (Eds.), Handbook of Constractionist Research (pp. 397-412). New York: Guliford Press.

[22] Douglas, D (2004). Grounded Theory and the 'And' in Entrepreneurship Research, Electronic Journal of Business Research Methods, 2(2): pp. 59-68.

[23] Hitt, M, A. Ireland,R. D, Sirmon, D, G. and Trahms, C A. (2017). Strategic Entrepreneurship: Creating Value for Individuals, Organizations, and Society, Academy of Management Perspectives, 25(2): pp. 57-75.

[24] Samson, D and Gloet, M (2016). creating new value, Innovation and Entrepreneurship: Creating New Value, Oxford University Press.

[25] Koller, T, Marc Goedhart, M \& Wessels, D (2010). Valuation Measuring and Value of Companition $\left(5^{\mathrm{Ed}}\right)$, John Wiley \& Sons, INC.

[26] Crossan,M \& Apaydin, (2010). A Multi-Dimensional Framework of Organizational Innovation: A Systematic Review of the Literature, Journal of Management Studies, 47(6): pp. 1154-1191.

[27] Lewrick, M., Omar, M., Raeside, R. and Sailer, K. (2010). Education for entrepreneurship and innovation: management capabilities for sustainable growth and success, World Journal of Entrepreneurship, Management and Sustainable Development, 6 (1): pp. 1-18.

[28] Drucker, P. F. (1985). Innovation and entrepreneurship: Practice and principles. New York: Harper \& Row.

[29] Romero, F. (2015). University-Industry Relations and Entrepreneurship. 10 ${ }^{\text {th }}$ European Conference on Innovation and Entrepreneurship - ECIE 2015, University of Genoa, Italy.

[30] Lincoln, Y. S., \& Guba, E. G. (1985). Naturalistic inquiry. Newbury Park, CA: Sage.

[31] Kirby, D., Guerrero, M., \& Urbano, D. (2011). Making universities more entrepreneurial: Development of a model. Canadian Journal of Administrative Sciences, 28(3), pp. 302-316.

[32] Link, A.N., Siegel, D.S., \& Bozeman, B. (2007). An empirical analysis of the propensity of academics to engage in informal university technology transfer, Industrial and Corporate Change, 16: pp. 641-655

[33] Etzkowitz, H., Klofsten, M. (2005). The innovating region: toward a theory of knowledge-based regional development. $R \& D$ Management, 35(3), pp. 243-255.

[34] Elche, D, Martínez-Pérez, Á, García-Villaverde, P, M. (2017). Inter-Organizational Relationships, Knowledge Strategy and Innovation in Clusters of Cultural Tourism, Investigaciones Regionales, Journal of Regional Research, 39: pp. 17-37.

[35] Weiss, B (2016). Role of the 'entrepreneurship university' in society, https://www.universityworldnews.com/post.php? story $=20160806165840303$

[36] Kerr, W, R. and Nanda, R (2014). Financing Constraints and Entrepreneurship, Working Paper, pp. 10013.

[37] Caspar-Terizakis, C. and Yu, X (2016). Definition, benefitsandformsof strategic partnership: https://www.daad.de/medien/hochschulen/ww/... .pdf

[38] Gibb, A., (2002), In pursuit of a new enterprise and entrepreneurship paradigm for learning: creative deconstruction, new values, new ways of doing things and new combinations of knowledge. International Journal of Management Reviews, 4(3): pp. 233-269.

[39] Shepherd, D. A. and E. J. Douglas (1997). Is management education developing, or killing, the entrepreneurial spirit? United States Association for Small Business and Entrepreneurship Conference, San Francisco, CA.

[40] Etzkowitz, H. (2003). Research groups as "quasi-firms": the invention of the entrepreneurial university, Research Policy, 32: pp. 109-121.

[41] Robles, H. J. (1998). Interdisciplinary Courses and Programs: Pedagogy and Practice. A Repot Available on ERIC.

[42] Bednar and Page. (2018). When Order Affects Performance: Culture, behavioural spill-overs and institutional path dependence. American Political Science Review, 112(1): pp. 82-98.

[43] OECD (2010). University Enterpreneurship Support: Policy Issues, Good Practices and Recommendation. (http://www.oecd.org/education/imhe/46588578.pdf)

[44] Bosman, L. and Fernhaber, S.(2018). Teaching the Entrepreneurial Mindset to Engineers, Springer International Publishing AG.

[45] Luhtanen, R \& Crocker, J (1992). A Collective Self-Esteem Scale: Self-Evaluation of One's Social Identity, Personality and Social Psychology Bulletin. 18(3):302-318.

[46] Frese, M (2009). Towards a psychology of entrepreneurship - An action theory perspective, Foundations and Trends in Entrepreneurship, 5 (6): pp. 437-496.

[47] Lacetera, N. (2008). Academic Entrepreneurship, MIT doctoral dissertation, USA, Massachusetts and lessons for Europe, Presented for European Commission as part of the KEINS project. USA: http://ftp.unibocconi.it/pub/RePEc/cri/papers/WP180Fr anzoniLissoni.pdf.

[48] Geuna, A., Salter, A. and Steinmueller, W.E. (eds.), (2003). Science and innovation, Edward Elgar. 
[49] Crespo, M., Dridi, H. (2007). Intensification of university-industry relationships and its impact on academic research, Higher Educational, 54(12): pp. 61-81.

[50] Audretsch, D, B. Aldridge, T and Nadella, V, K. (2013). University Science Faculty Ventures into Entrepreneurship (https://www.sba.gov/sites/default/files/files/rs409tot... .pdf).

[51] Oliveira, L, (2000). Commodification of Science and Paradoxes in Universities, Science Study, 2: pp. 23-36.

[52] Chrisman, J., Hynes, T., \& Fraser, S. (1995). Faculty Entrepreneurship and Economic development: The Case of the University of Calgary. Journal of Business Venturing, 10: pp. 267-81.

[53] Gibbons, M., Limoges, C., Nowotny, H., Schwartzman, S., Scott, P., Trow, M. (1994). The New Production of Knowledge: The Dynamics of Science and Research in Contemporary Society, Sage Publications, London.

[54] Etzkowitz H, Gulbrandsen M, Levitt J (2000). Public Venture Capital. New York, NY: Harcourt.

[55] Etzkowitz, H (2013). Anatomy of the entrepreneurial university, Social Science Information, 52(3) pp. 486-511.

[56] Guenther, J., Wagner, K. (2008). "Getting out of the ivory tower: new perspectives on the entrepreneurial university”. European Journal of International Management, 2(4): pp. 400-417.

[57] Etzkowitz, H. (1983). "Entrepreneurial Scientists and Entrepreneurial Universities in American Academic Science”. Minerva, 21(2-3): pp. 198-233.

[58] Guerrero, M., Urbano, D., \& Salamzadeh, A. (2014). Evolving entrepreneurial universities: Experiences and challenges in the Middle Eastern context. In Handbook on the Entrepreneurial University. Edward Elgar Publishing.

[59] Guerrero, M., Urbano, D., \& Salamzadeh, A. (2015). Entrepreneurial transformation in the Middle East: experiences from Tehran Universities. Technics Technologies Education Management, 10(4): pp. 533537.

[60] Guerrero, M., Urbano, D., Cunningham, J., Organ, D. (2014). Entrepreneurial universities in two European regions: a case study comparison. The Journal of Technology Transfer, 39 (3): pp. 415-434.

[61] Salamzadeh, A., Farsi, J. Y., Motavaseli, M., Markovic, M. R., \& Kesim, H. K. (2015). Institutional factors affecting the transformation of entrepreneurial universities. International Journal of Business and Globalisation, 14(3), pp. 271-291.

[62] Salamzadeh, A., Kesim, H. K., \& Salamzadeh, Y. (2016). Entrepreneurial universities and branding: A conceptual model proposal. World Review of Science, Technology and Sustainable Development, 12(4), pp. 300-315.

[63] Fayolle, A., and Redford, D. T. (Eds.) (2014) Handbook on the entrepreneurial university, Northampton, MA: Edward Elgar.

[64] Etzkowitz, H. (2004). The evolution of the Entrepreneurial University. International Journal of Technology and Globalization, 1: pp. 64-77.

[65] Mustar, P., M. Renault, et al., (2006). Conceptualising the Heterogeneity of Research-Based Spin-Offs: A Multi-Dimensional Taxonomy, Research Policy, 35(2): pp. 289-308.

[66] Dill, D.D and B. Sporn (1995). The Implications of a Postindustrial Environment for the University: An Introduction, in D.D. ill and B. Sporn (eds.), Emerging Patterns of Social Demand and University Reform: Through a Glass Darkly, IAU Press.

[67] Clark, B. R. (1998). Creating Entrepreneurial Universities. Oxford: Pergamon.

[68] Kirby, D.A. (2002b). Creating Entrepreneurial Universities: A Consideration. School of Management. Working Paper, University of Surrey.

[69] Muers, S, (2018). Culture, Values and Public Policy, Institute for Policy Research, University of $\mathrm{BACH}$.

\section{Article history:}

Received 17 February 2020

Accepted 20 April 2020 